\title{
Grand Rounds: An Impossible Life
}

Survival.

That's the name of the gene: Survival Motor Neuron.

Ironic that we say her problem was

Not enough "survival".

But in a way

A proteomic metaphor for her impossible life.

Not possible, life without SMN,

So she used some transcripts

From the other copy

And found a way to live.

Not possible, a "normal life".

Not possible, a regular class.

But you don't need muscles to think

So she found her way to Law School.

Travel? Not possible said the railway,

So she took their "not possible"

To the Supreme Court

And made it possible for everyone.

Love? marriage? Not possible.

Wrong.

You don't need muscles to love.

They found a way.

The docs said children were not possible;

"But not inconceivable!" she laughed.

A favourite joke

To go with the photo.

They got one thing right: this was no normal life.

What's not possible

Is to introduce

My patient, my friend

With impersonal initials.

She was not "C.M."

And she was never "a case".

She was Claire

And she made the impossible happen her whole life.

She would have laughed

To know that when I heard she had died

My first thought was

"Not possible."

\section{Catherine Elizabeth Pringle}

Corresponding to Catherine Elizabeth Pringle, University of Ottawa, Department of Medicine Neurology, Ottawa, Ontario, K1H 8L6 Canada; epringle@toh.ca

Competing interests None declared.

Provenance and peer review Not commissioned; internally peer reviewed.

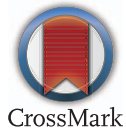

To cite Pringle CE. Med Humanit 2017;43:e17.

Published Online First 9 January 2017

Med Humanit 2017;43:e17. doi:10.1136/medhum-2016-011164 